\title{
PENGUATAN PERAN MAJELIS PERMUSYAWARATAN RAKYAT DALAM STRUKTUR KETATANEGARAAN INDONESIA
}

\author{
R. Nazriyah \\ * Dosen Universitas Muhammadiyah Gresik \\ Korespondensi: Ririesnaya@yahoo.com \\ Naskah dikirim: 27 Desember 2016 \\ Naskah diterima untuk diterbitkan: 3 Maret 2017
}

\begin{abstract}
Nevertheless, the amendment (fifth) should be done with wisdom, sincerity, deliberation, and After the constitutional amendment the Assembly's role was limited only on disseminate the results of the 1945 amendment and appoint President and Vice President. Lately the idea to strengthen the role of the Assembly is coming up, to restore the Assembly as the highest state institution even going back to use the Guidelines as the direction of national development that used to define the authority of the Assembly. Strengthening the role of the Assembly now has begun to appear with the revival of the tradition of the annual session of the Assembly, with less in this way the performance of the President and other state institutions can be controlled and serve as checks and balances. Discourse to reuse the guidelines need to consider the following matters: first, it should be clearly who is authorized to make. Second, in what legal form the guidelines set forth? If in the form of consultative assembly, then the consultative assembly should be revived. For that, it needs the affirmation of the matter and the legal status of consultative assembly within the Indonesian legal system, including provisional consultative assembly is still valid. It is better if you use the guidelines because if the President and Vice President are unable to attend, then the Assembly elect the President and Vice President as mandated by the constitution, the president and vice president "Consultative Assembly's selection" can continue development programs sourced from guidelines without any conflict of vision and mission. For that, the settings must be back to the Constitution, the amendment is a necessity. clearly grand design.
\end{abstract}

Keywords: Strengthening, Consultative Assembly, Tlahe constitutional structure of Indonesia

\begin{abstract}
Abstrak
Setelah amandemen UUD peran MPR hanya sebatas menjalankan tugas untuk menyosialisasikan hasil-hasil amandemen UUD 1945 dan melantik Presiden dan Wakil Presiden. Akhir-akhir ini muncul gagasan untuk menguatkan peran MPR, mengembalikan MPR sebagai Lembaga Tertinggi Negara bahkan akan
\end{abstract}


kembali menggunakan GBHN sebagai arah pembangunan nasional yang dulu menjadi wewenang MPR menetapkannya. Penguatan peran MPR kini sudah mulai nampak dengan dihidupkannya kembali tradisi Sidang Tahunan MPR, dengn cara ini kinerja Presiden dan lembaga-lembaga negara lainnya dapat dikontrol dan berfungsi sebagai checks and balances. Wacana untuk menggunakan kembali GBHN perlu mempertimbangkan hal-hal sebagai berikut: pertama, harus diatur secara jelas siapa yang berwenang membuatnya. Kedua, dalam bentuk hukum apa GBHN dituangkan? Jika dalam bentuk ketetapan MPR, maka ketetapan MPR harus dihidupkan kembali. Untuk itu, perlu adanya penegasan tentang materi dan status hukum ketetapan MPR dalam sistem hukum Indonesia termasuk ketetapan MPR/S yang masih dinyatakan berlaku. Ada baiknya jika menggunakan GBHN sebab, jika Presiden dan Wakil Presiden berhalangan tetap secara bersamaan dan MPR memilih Presiden dan Wakil Presiden sesuai amanat konstitusi, maka Presiden dan Wakil Presiden "pilihan MPR" dapat melanjutkan program pembangunan yang bersumber dari GHBN tanpa adanya benturan visi dan misi. Untuk itu, pengaturannya harus dikembalikaan kepada UUD, amandemen ulang merupakan suatu keniscayaan. Kendati demikian, amandemen (kelima) harus dilakukan secara hikmat, penuh kesungguhan, pertimbangan yang mendalam, dan grand design yang jelas.

Kata Kunci: Penguatan, Majelis Permusyawaratan Rakyat, Struktur Ketatanegaraan Indonesia

\section{Pendahuluan}

Berdasarkan Pasal 1 ayat (2) UUD 1945 (Sebelum Perubahan) dan Penjelasan UUD 1945, bahwa kekuasaan Negara yang tertinggi di tangan MPR. Majelis ini dianggap sebagai penjelmaan rakyat yang memegang kedaulatan negara. MPR adalah lembaga negara yang mempunyai kedudukan dan kekuasaan yang tertinggi. Kekuasaannya tidak terbatas dan tidak ditetapkan secara limitatif melainkan enumeratif yang bersumber pada Pasal 1 ayat (2) itu sendiri. Dengan demikian Majelis mempunyai kedudukan yang tertinggi di antara Lembaga-lembaga negara lainnya. ${ }^{1}$ Keanggotaan MPR sebagaimana diatur dalam Pasal 2 ayat (1) terdiri atas anggota DPR ditambah Utusan Daerah dan Utusan Golongan.

\footnotetext{
${ }^{1}$ MPR adalah Lembaga Tertinggi Negara yang merupakan penjelmaan (manifestasi) dari keseluruhan aspirasi rakyat. Sri Soemantri, Kedudukan Lembaga-lembaga Negara dan Hak Menguji Menurut UUD 1945, Cetakan Pertama, (Jakarta: Sinar Grafika, 1987), hlm. 45
} 
Menurut teori ilmu hukum tata negara Indonesia, MPR merupakan satu-satunya lembaga yang mempunyai supremasi, yang mengandung dua prinsip: ${ }^{2}$

1. Sebagai badan berdaulat yang memegang kekuasaan berdasarkan hukum untuk menetapkan segala sesuatu yang telah ditegaskan oleh UUD 1945, disebut "legal power".

2. no rival authority, artinya tidak ada suatu otoritas tandingan baik perseorangan maupun badan yang mempunyai kekuasaan untuk melanggar atau menyampingkan sesuatu yang telah diputuskan oleh MPR.

Setelah adanya Perubahan UUD 1945, Pasal 1 ayat (2) mengalami perubahan yaitu, kedaulatan berada di tangan rakyat dan dilaksanakan menurut Undang-Undang Dasar. Dengan adanya perubahan tersebut MPR tidak lagi sebagai lembaga tertinggi negara melainkan sederajat dengan lembaga-lembaga negara lainnya. ${ }^{3}$ Kewenangannya pun hanya sebatas mengubah dan menetapkan UUD, melantik Presiden dan Wakil Presiden, dan memberhentikan Presiden dan/atau Wakil Presiden dalam masa jabatannya menurut UUD. ${ }^{4}$ Susunan anggota MPR juga mengalami perubahan, Pasal 2 ayat (1) UUD 1945 Setelah Perubahan menegaskan bahwa anggota MPR terdiri atas anggota DPR dan anggota DPD yang dipilih melalui pemilihan umum. Sistem perwakilan ini dikenal dengan sistem dua kamar (bikameral).

Ada tiga alasan yang menyebabkan perlunya penyesuaian terhadap susunan, kedudukan, dan kekuasaan MPR menjadi suatu lembaga perwakilan rakyat dengan dua kamar (bikameral). Salah satu di antaranya adalah, ${ }^{5}$ kebutuhan bagi Indonesia saat ini untuk mulai menerapkan sistem checks and

\footnotetext{
2 Ismail Suny, Mekanisme Demokrasi Pancasila, (Jakarta: Aksara Baru, 1978), hlm. 16.

${ }^{3}$ Oleh Philipus M. Hadjon dikatakan bahwa perubahan ketiga (Pasal 1 ayat (2) dan Pasal 3 UUD 1945) membawa konsekuensi fundamental terhadap kedudukan dan fungsi MPR. Perubahan terhadap Pasal 1 ayat (2) UUD 1945 telah menggusur doktrin supremasi MPR yang telah menjadikan MPR sebagai Lembaga Tertinggi Negara secara inkonstitusional. Salmon E.M.Nirahua, "Kedudukan dan Kewenangan Dewan Perwakilan Daerah dalam Sistem Ketatanegaraan Indonesia”, dalam Jurnal Hukum Ius Quia Iustum, Vol. 18 No. 4, Yogyakarta, Oktober 2011, hlm. 587. Dalam hal ini Moh. Mahfud MD menegaskan, MPR bukan lagi lembaga tertinggi negara, sebab sekarang tidak ada lagi lembaga tertinggi dan lembaga tinggi negara yang dibedakan secara vertikal-struktural, yang ada sekarang adalah lembaga negara yang dibedakan secara horizontal-fungsional saja. Moh. Mahfud MD, Perdebatan Hukum Tata Negara Pasca Amandemen Konstitusi, Cetakan ke 2,( Jakarta: PT. RajaGrafindo Persada, 2011), hlm. 53.

${ }^{4}$ Pasal 3 ayat (1), (2), dan (3) UUD 1945 Setelah Perubahan.

${ }^{5}$ http://perpustakaan.bappenas.go.id. MPR Pasca perubahan UUD 1945.htm diakses tanggal 25 Mei 2012. Mereposisi susunan DPR, DPD, dan MPR dalam sistem ketatanegaraan Indonesia merupakan upaya menciptakan sistem check and balances di antara lembagalembaga negara. Perubahan pasal-pasal UUD 1945 yang mengatur lembaga perwakilan merupakan upaya memperbaiki sistem perwakilan yang selama ini telah melahirkan MPR dengan kekuasaan tidak terbatas, Presiden yang terlampau kuat, serta legislatif yang lemah. Valina Singka Subekti, Menyusun Konstitusi Transisi: Pergulatan Kepentingan dan Pemikiran dalam Proses Perubahan UUD 1945, (Jakarta: Rajawali Pers, 2008), hlm. 317.
} 
balances dalam rangka memperbaiki kehidupan ketatanegaraan dan mendorong demokratisasi. Dengan adanya lembaga perwakilan rakyat dengan dua kamar, maka diharapkan lembaga ini akan mampu menjalankan fungsi legislasi dan fungsi kontrolnya dengan lebih baik.

Pertanyaannya sekarang adalah, apakah sistem checks and balance selama ini sudah berfungsi sebagaimana mestinya? Apakah lembaga-lembaga negara yang ada sudah menjalankan kewenangannya secara proporsional? Apabila kita perhatikan beberapa kewenangan lembaga negara yang semakin meluas dan keluar dari apa yang telah diberikan oleh UUD. Misalnya, Mahkamah Konstitusi dengan kewenangannya yang semakin "menggurita" melalui perkembangan putusan-putusannya (conditionally constitutional, conditionally unconstitutional, perumusan norma dalam putusan). DPD yang sering berkeluh kesah dengan mirisnya kewenangan yang dimilikinya, demikian juga peran Komisi Yudisial yang kurang optimal dalam fungsinya sebagai lembaga yang mengawasi kinerja Hakim menyebabkan carut marutnya sistem ketatanegaraan Indonesia.

Carut marutnya sistem ketatanegaraan dan terjadinya kegaduhan politik, membuka cahaya kesadaran untuk menata ulang dan terbersit menjadikan MPR sebagai "wasit" manakala terjadi hubungan kurang harmonis di antara lembaga lembaga tinggi negara, atau ada lembaga negara yang bermain di luar lapangan sehingga menganggu ketenangan "netizen" dan mengembalikan MPR sebagai lembaga tertinggi negara.

Wacana mengembalikan MPR sebagai Lembaga Tertinggi Negara mengundang kontroversi dari berbagai kalangan. Pihak yang setuju menyatakan, jika MPR kembali menjadi lembaga tertinggi negara, bisa menjadi pengayom lembaga- lembaga tinggi negara.

Sedangkan Pengamat Hukum dan Tata Negara Refly Harun menegaskan, ${ }^{6}$ usulan mengembalikan MPR sebagai Lembaga Tertinggi Negara merupakan usulan kemunduran dari jalannya sistem demokrasi di Tanah Air. Di samping itu, akan melemahkan sistem check and balances antarlembaga tinggi Negara. Padahal, untuk menjamin demokrasi berjalan baik, seluruh lembaga tinggi negara harus ada sistem check and balances. Jika sistem check and balances tidak terpenuhi, maka salah satu lembaga negara berpotensi tumbuh secara otoriter itu harus dihindari.

Di samping itu, ada yang mengatakan bahwa pembangunan nasional sekarang ini dilakukan tanpa arah, penetapan sebuah model Garis Besar Haluan Negara (GBHN) seperti Orde Baru yang berfungsi sebagai panduan ideologis bagi jalannya pembangunan nasional dianggap sebagai kepentingan mendesak. Tetapi, ada juga yang menilai GBHN dan Rencana Pembangunan Jangka Menengah (RPJM) dan Rencana Pembangunan Jangka Panjang (RPJP) yang tecantum dalam UU No. 25 Tahun 2004 Tentang Sistem Perencanaan Pembangunan Nasional (SPPN) yang dipergunakan saat ini adalah sama hanya namanya yang berbeda bahkan lebih lengkap dari GBHN.

6 Kedudukan MPR: hindari munculnya lembaga otoriter, <http://k kabar24. bisnis.com /read /20140922 /15/259180/>, diakses tanggal 15 September 2016. 
Semua yang dijabarkan di atas berkaitan dengan "hak milik" yang pernah dimiliki oleh MPR kemudian hilang akibat adanya Perubahan UUD. Sekarang MPR berusaha untuk "menariknya" kembali dan berpandangan perlunya kembali melakukan perubahan pada UUD 1945. Perubahan itu dinilai perlu untuk menguatkan fungsi dan wewenang MPR sehingga MPR lebih diberdayakan.

Upaya untuk memberdayakan MPR sebagai agenda reformasi terus diwacanakan, seiring bergulirnya keinginan untuk melakukan amandemen ulang (kelima) terhadap UUD 1945 akibat kekacauan ketatanegaraan yang terus menggerus tatanan kebangsaan yang diupayakan menjadi mapan.

Berdasarkan uraian di atas permasalahan yang hendak dikaji adalah, Pertama, bagaimana pasang surut peran MPR sebagai lembaga tertinggi negara? Kedua, bagaimana upaya menguatkan peran MPR di kemudian hari dan menyempurnakan penataan ulang sistem ketatanegaraan?

\section{Struktur Kekuasaan Negara}

Pada hakikatnya, dalam ide kedaulatan rakyat itu, tetap harus dijamin bahwa rakyatlah yang sesungguhnya pemilik negara dengan segala kewenangannya untuk menjalankan semua fungsi kekuasaan negara, baik di bidang legislatif, eksekutif, maupun yudikatif. Rakyatlah yang berwenang merencanakan, mengatur, melaksanakan, dan melakukan pengawasan serta penilaian terhadap pelaksanaan fungsi-fungsi kekuasaan itu. Bahkan lebih jauh lagi untuk kemanfaatan bagi rakyatlah sesungguhnya segala kegiatan ditujukan dan diperuntukkan segala manfaat yang didapat dari adanya dan berfungsinya kegiatan bernegara itu. Inilaj gagasan kedaulatan rakyat yang bersifat 'total' dari rakyat, untuk rakyat, oleh rakyat dan bersama rakyat. ${ }^{7}$

Pasal 3 ayat (1) Undang-Undang Dasar Republik Indonesia menyebutkan bahwa kedaulatan ada di tangan rakyat dan didasarkan pada Undang-Undang Dasar. ${ }^{8}$ Hal ini mencerminkan bahwa kedaulatan berada di atas segalanya. Kedaulatan rakyat yang disebut juga dengan supremasi rakyat merupakan salah satu unsur yang ditempatkan paling kuat dalam bentuk pemerintahan yang demokratis. ${ }^{9}$

Dari segi kelembagaan, prinsip kedaulatan rakyat itu biasanya diorganisasikan melalui dua pilihan cara, ${ }^{10}$ yaitu melalui sistem pemisahan

${ }^{7}$ Jimly Asshiddiqie, Konstitusi dan Konstitusionalisme Indonesia, Cetakan Pertama, (Jakarta: diterbitkan atas kerja sama: Mahkamah Konstitusi dan Pusat Studi Hukum Tata Negara FH UI, 2004), hlm. 114.

${ }^{8}$ Republik Indonesia, Undang-Undang Dasar 1945 Perubahan Keempat, Pasal 3 ayat

9 Ramly Hutabarat, "Politik Hukum Pemerintahan Soeharto tentang Demokrasi Politik di Indonesia”, (Jakarta: Pusat Studi Hukum Tata Negara FHUI: 2005), hal. 1. Dalam Ryan Muthiara Wasti." Pengaruh Konfigurasi Politik Terhadap Produk Hukum Pada Masa Pemerintahan Soeharto Di Idonesia", Jurnal Hukum dan Pembangunan, Tahun ke-45 No.1 Januari-Maret 2015, hlm. 87.

10 Jimly Asshiddiqie, Konstitusi dan Konstitusionalisme Indonesia, Cetakan Pertama, (Jakarta: diterbitkan atas kerja sama: Mahkamah Konstitusi dan Pusat Studi Hukum Tata Negara FH UI, 2004), hlm. 133. 
kekuasaan (separation of power) atau pembagian kekuasaan (distribution of power). Pemisahan kekuasaan bersifat horizontal dalam arti kekuasaan dipisah-pisahkan ke dalam fungsi-fungsi yang tercermin dalam lembagalembaga negara yang sederajat dan saling mengimbangi (checks and balances). Sedangkan pembagian kekuasaan bersifat vertikal dalam arti perwujudan kekuasaan itu dibagikan secara vertikal ke bawah kepada lembaga-lembaga tinggi negara di bawah lembaga pemegang kedaulatan rakyat.

Sebelum adanya Perubahan UUD 1945, Indonesia menganut sistem pembagian kekuasaan, benarkah demikian? Montequieu dalam bukunya L'Esprit des Lois membagi kekuasaan negara ke dalam tiga cabang kekuasaan yaitu, kekuasaan eksekutif, kekuasaan legislatif dan kekuasaan yudikatif. ${ }^{11}$ Menurut ajaran Trias Politica tersebut, kekuasaan negara itu harus dipisah-pisahkan dan masing-masing dilakukan oleh organ tersendiri. Pemisahan kekuasaan itu bersifat kedap, dalam arti bahwa kekuasaankekuasaan bukan hanya dibeda-bedakan dan dipisah-pisahkan satu sama lain, tetapi harus pula diserahkan dan dilakukan oleh organ-organ negara yang terpisah. Adanya pemisahan ini dimaksudkan untuk mencegah supaya kekuasaan negara itu itu tidak berada pada satu tangan/organ saja sehingga dikhawatirkan dapat menimbulkan penyalahgunaan oleh organ tersebut. ${ }^{12}$

Dalam praktik kehidupan kenegaraan ternyata ajaran Trias Politica itu tidak dapat diterapkan secara mutlak, pengertian fungsi kekuasaan negara dan organ negara perlu ada pembedaan. Selain itu, satu organ negara mungkin dapat melakukan lebih dari satu fungsi kekuasaan negara. ${ }^{13}$

Sesuai dengan ketentuan-ketentuan dalam UUD 1945 beserta Penjelasannya (sebelum perubahan), pemegang ketiga kekuasaan itu di Indonesia adalah sebagai berikut: kekuasaan eksekutif dipegang oleh Presiden; kekuasaan legislatif dipegang oleh Presiden dengan persetujuan DPR; dan kekuasaan yudikatif dipegang oleh MA dan badan-badan Peradilan lainnya. ${ }^{14}$ Dengan adanya kekuasaan eksekutif di tangan Presiden sekaligus kekuasaan legislatif (dengan persetujuan DPR), maka sebenarnya kita tidak menganut ajaran Trias Politica atau sistem pemisahan kekuasaan melainkan pembagian kekuasaan. ${ }^{15}$

Selama ini, UUD 1945 menganut paham pembagian kekuasaan yang bersifat vertikal, bukan pemisahan kekuasaan yang bersifat horizontal. Kedaulatan rakyat dianggap terwujud penuh dalam wadah MPR yang dapat ditafsirkan sebagai lembaga tertinggi ataupun sebagai forum tertinggi. Dari sini, fungsi-fungsi tertentu dibagikan sebagai tugas dan kewenangan lembaga-lembaga tinggi negara yang ada di bawahnya, baik kepada lembaga eksekutif, legislatif maupun yudikatif, yaitu Presiden, DPR, MA, dan

\footnotetext{
${ }^{11}$ Maria Farida Indrati Soeprapto, Ilmu Perundang-undangan Dasar-Dasar dan Pembentukannya, (Yogyakarta: Kanisius, 1998), hlm. 60-61.

${ }^{12}$ Ibid.

${ }^{13}$ Ibid.

${ }^{14}$ Ibid.

${ }^{15}$ Ibid.
} 
seterusnya. ${ }^{16}$ Sedangkan BPK lebih menyangkut fungsi verifikatif/akuntatif dan DPA menyangkut fungsi konsultatif dan advisory. ${ }^{17}$

Dalam perspektif pembagian kekuasaan yang bersifat vertikal itu, prinsip kesederajatan dan perimbangan kekuasaan itu tidaklah bersifat primer. Karena itu, dalam UUD 1945 yang asli, tidak diatur pemisahan yang tegas dari fungsi legislatif dan eksekutif. Dalam sistem yang lama, fungsi DPR lebih merupakan lembaga pengawas daripada lembaga legislatif dalam arti yang sebenarnya. Menurut Jimly Asshiddiqie, dalam Perubahan Pertama dan Kedua UUD 1945, prinsip pemisahan kekuasaan secara tegas mulai dianut oleh para perumus Perubahan UUD seperti tercermin dalam perubahan Pasal 5 ayat (1) dan Pasal 20 ayat (1) sampai ayat (5). ${ }^{18}$ Sedangkan Bagir Manan mengatakan bahwa, setelah Perubahan UUD 1945 sistem ketatanegaraan Indonesia makin mendekati sistem pemisahan kekuasaan (separation of powers). Disebut "makin mendekati", karena Presiden masih diberi hak mengajukan rancangan undang-undang dan ikut bersama DPR membahas rancangan undang-undang. Hubungan antara alat-alat kelengkapan negara semata-mata didasarkan sistem checks and balances bukan hubungan organik atau fungsional. ${ }^{19}$

Anutan prinsip pembagian kekuasaan atau pemisahan kekuasaan ini penting untuk dijernihkan karena pilihan di antara keduanya sangat mempengaruhi mekanisme kelembagaan dan hubungan antar lembaga negara secara keseluruhan. Dalam paham pemisahan kekuasaan, prinsip hubungan checks and balances antara lembaga-lembaga tinggi negara, dianggap sebagai sesuatu yang sangat pokok. Oleh karena itu, dengan ditegaskannya anutan prinsip pemisahan kekuasaan maka format dan mekanisme ketatanegaraan yang dikembangkan pada masa depan juga mengalami perubahan mendasar. Kekuasaan negara yang selama ini terpusat pada MPR sebagai lembaga tertinggi negara, termasuk berkenaan dengan format dan susunan peraturan

16 Jimly Asshiddiqie, Konstitusi dan Konstitusionalisme Indonesia, Cetakan Pertama, (Jakarta: diterbitkan atas kerja sama: Mahkamah Konstitusi dan Pusat Studi Hukum Tata Negara FH UI, 2004), hlm. 180

17 Jimly Asshiddiqie, Format Kelembagaan dan Pergeseran Kekuasaan Dalam UUD 1945, Cetakan Pertama, (Yogyakarta: FH UII Press, 2004), hlm. 180. Dalam teori hukum tata negara tidak ada organ negara yang secara hukum lebih tinggi atau lebih rendah. Setiap organ negara mempunyai kedudukan dan wewenang yang sesuai dengan aturan hukum yang mengaturnya. Sebagai lingkungan jabatan, organ negara memiliki sendirisendiri lingkungan wewenang yang ditentukan oleh hukum bukan oleh hubungan hierarki antara organ yang satu dengan yang lain. Bagir Manan, Teori dan Politik Konstitusi, Cetakan Pertama, (Yogyakarta: FH UII Press, 2003), hlm. 214.

18 Jimly Asshiddiqie. Konstitusi dan Konstitusionalisme Indonesia, Cetakan Pertama, (Jakarta: diterbitkan atas kerja sama: Mahkamah Konstitusi dan Pusat Studi Hukum Tata Negara FH UI, 2004), hlm.. 133.

${ }^{19}$ Bagir Manan. Teori dan Politik Konstitusi, Cetakan Pertama, (Yogyakarta: FH UII Press, 2003), hlm. 80. 
perundang-undangan yang selama ini terkait dengan keberadaan MPR, mau tidak mau, harus mengalami perubahan mendasar. ${ }^{20}$

Dengan pemisahan kekuasaan dapat dicegah penumpukan kekuasaan di satu tangan (absolut) yang akan menimbulkan kekuasaan sewenangwenang. Di zaman sekarang, doktrin pemisahan kekuasaan (separation of powers) cenderung dikembangkan menjadi doktrin pembagian kekuasaan (division of powers) disertai prinsip "checks and balances", agar masingmasing organ tidak saja saling mengawasi, tetapi juga mempunyai kedudukan yang seimbang dan sederajat yang dalam doktrin klasik sulit untuk diharapkan, dan karena itu sukar pula melakukan pengawasan terhadap pemerintah. ${ }^{21}$

Setelah adanya perubahan Undang-Undang Dasar 1945, sistem ketatanegaraan Indonesia pun telah mengalami perubahan-perubahan yang sangat mendasar. Perubahan-perubahan itu juga mempengaruhi struktur dan mekanisme struktural organ-organ negara Republik Indonesia yang tidak dapat lagi dijelaskan menurut cara berpikir lama. Dalam kaitannya dengan kedaulatan rakyat, Jimly Asshiddiqie mengemukakan, ${ }^{22}$ kedaulatan rakyat Indonesia itu diselenggarakan secara langsung dan melalui sistem perwakilan. Secara langsung, kedaulatan rakyat itu diwujudkan dalam tiga cabang kekuasaan yang tercermin dalam MPR yang terdiri dari DPR dan DPD; Presiden dan Wakil Presiden; dan kekuasaan kehakiman yang terdiri atas Mahkamah Konstitusi dan Mahkamah Agung. Dalam menentukan kebijakan pokok pemerintahan dan mengatur ketentuan-ketentuan hukum berupa undang-undang dasar dan undang-undang (fungsi legislatif), serta dalam menjalankan fungsi pengawasan (fungsi kontrol) terhadap jalannya pemerintahan, pelembagaan kedaulatan rakyat itu disalurkan melalui sistem perwakilan, yaitu melalui MPR, DPR dan DPD. Di daerah-daerah provinsi dan kabupaten/kota, pelembagaan kedaulatan rakyat itu juga disalurkan melalui sistem perwakilan, yaitu melalui DPRD.

Dalam tulisannya yang lain Jimly Asshiddiqie mengatakan bahwa, ${ }^{23}$ MPR tetap merupakan rumah penjelmaan seluruh rakyat yang strukturnya dikembangkan dalam dua kamar, yaitu DPR dan DPD. Oleh karena itu, prinsip perwakilan daerah dalam DPD harus dibedakan hakikatnya dari prinsip perwakilan rakyat dalam DPR. Maksudnya ialah agar seluruh aspirasi rakyat

${ }^{20}$ Jimly Asshiddiqie, Konstitusi dan Konstitusionalisme Indonesia, Cetakan Pertama, (Jakarta: diterbitkan atas kerja sama: Mahkamah Konstitusi dan Pusat Studi Hukum Tata Negara FH UI, 2004), hlm.. 133.

${ }^{21}$ Ibrahim bin Ismail, "The General Characteristics of the Parliamentary System of Government under the Malaysian Constitution”, IIU Law Journal, Vol. 1 2/July 1989. hlm. 11. dalam Jimly Asshiddiqie, Pergumulan Peran Pemerintah dan Parlemen Dalam Sejarah Telaah Perbandingan Konstitusi Berbagai Negara, Jakarta, UI Press, 1996, hlm. 61.

22 Jimly Asshiddiqie, "Struktur Ketatanegaraan Indonesia setelah Perubahan Keempat UUD Tahun 1945." Makalah Seminar Pembangunan hukum Nasional VIII Tema "Penegakan Hukum Dalam Era Pembangunan Berkelanjutan” Diselenggarakan oleh Badan Pembinaan Hukum nasional Departemen Kehakiman dan Hak Asasi Manusia RI. Denpasar, 14 - 18 Juli 2003.

${ }^{23}$ Ibid., hlm. 4. 
benar-benar dapat dijelmakan ke dalam MPR yang terdiri dari dua pintu itu. Kedudukan MPR yang terdiri dari dua lembaga perwakilan itu adalah sederajat dengan Presiden, Mahkamah Agung dan Mahkamah Konstitusi. Ketiga cabang kekuasaan legislatif, eksekutif, dan yudikatif itu sama-sama sederajat dan saling mengontrol satu sama lain sesuai dengan prinsip checks and balances. Dengan adanya prinsip cheks and balances ini, maka kekuasaan negara dapat diatur, dibatasi dan bahkan dikontrol dengan sebaik-baiknya, sehingga penyalahgunaan kekuasaan oleh aparat penyelenggaraan negara ataupun pribadi-pribadi yang kebetulan sedang menduduki jabatan dalam lembagalembaga negara yang bersangkutan dapat dicegah dan ditanggulangi dengan sebaik-baiknya.

Dalam Undang-Undang Dasar 1945 setelah perubahan, rakyat masih memberi "kewenangan" kepada MPR seperti mengubah dan menetapkan konstitusi, melantik Presiden dan Wakil Presiden, melakukan impeachment termasuk menyelenggarakan sidang sedikitnya sekali dalam lima tahun. Karena itu, meski kedaulatan tidak lagi dilaksanakan sepenuhnya oleh MPR, bukan berarti MPR setelah perubahan UUD 1945 kehilangan semua kewenangan. Rakyat sebagai pemegang kedaulatan melalui perubahan UUD 1945 masih sepakat memberikan beberapa kewenangan kepada MPR. Namun, pada perubahan ketiga Pasal 6A UUD 1945 untuk memilih Presiden dan Wakil Presiden, rakyat ingin melaksanakannya sendiri dan menarik kewenangan yang pernah diberikan kepada MPR. ${ }^{24}$

\section{Sistem Pemerintahan}

Sejak dulu UUD 1945 dikatakan menganut sistem pemerintahan presidentil. Namun demikian, jika ditelaah secara seksama, sistem presidensiil yang dianut dalam UUD 1945 sama sekali tidak murni sifatnya. ${ }^{25}$ Hal ini nampak karena adanya pengaturan dalam UUD 1945 tentang pertanggungjawaban Presiden kepada MPR sebagai ciri pokok dari sistem parlementer.

Perkembangan sistem pemerintahan di Indonesia menuju ke arah yang semakin unik. Di lembaga kepresidenan bertahan dengan sistem presidensil, tetapi semangat yang berkembang di bidang pemerintahan menuju ke arah sistem parlementer. Kewenangan yang dimiliki Presiden untuk membubarkan parlemen, pada umumnya diikuti oleh sistem parlementer. Pemberhentian Presiden dengan alasan pelanggaran haluan negara atau pertanggungjawaban politik adalah pengaruh sistem parlementer. Pembentukan kabinet dengan menggunakan sistem koalisi adalah kebiasaan sistem parlementer. Kondisi

24 Ibid.

25 Jimly Asshiddiqie, Hukum Tata Negara dan Pilar-Pilar Demokrasi, Cetakan Kedua, (Jakarta:Konstitusi Press, 2005), hlm. 108. 
kejiwaan tentang pemahaman kekuasaan eksekutif dan kekuasaan parlemen itu, mempersulit proses perubahan sistem yang ada. ${ }^{26}$

Perubahan sistem pemilihan Presiden secara langsung adalah konsekuensi sistem presidensial, sedangkan sistem pembentukan kabinet, pengawasan dan pertanggungjawaban kebijakan politik cenderung ke sistem parlementer. Kecenderungan ke arah sistem parlementer dapat pula dilihat dari cara pembentukan kabinet yang tidak sepenuhnya menjadi kewenangan Presiden. Partai politik besar mempunyai pengaruh yang besar dalam penyusunan kabinet. ${ }^{27}$

Sistem pemerintahan yang dikenal di dunia dewasa ini dapat dirumuskan ke dalam empat model, yaitu model Inggris, Amerika Serikat, Perancis, dan Swiss. ${ }^{28}$ Amerika Serikat menganut sistem presidensiil. Hampir semua negara di benua Amerika kecuali beberapa negara seperti Kanada, meniru Amerika Serikat dalam hal ini. Di Benua Eropa dan kebanyakan negara Asia pada umumnya menggunakan model Inggris, yaitu sistem parlementer.

Presidensialisme memiliki kelebihan dalam stabilitas eksekutif, demokrasi yang lebih besar dan pemerintahan yang lebih terbatas, dan kekurangannya dalam kemandegan (deadlock) eksekutif-legislatif, kekakuan temporal dan pemerintahan yang kurang inklusif (kekuasaan dipegang sepenuhnya). Parlementarisme memiliki konsekuensi sebaliknya; kelebihan presidensialisme adalah kekurangan parlementarisme dan sebaliknya. ${ }^{29}$

Sedangkan Perancis memiliki model tersendiri yang bersifat campuran atau yang biasa disebut "hybrid system". Pada umumnya negara-negara bekas jajahan Perancis di afrika menganut sistem campuran. Di satu segi ada pembedaan antara Kepala Negara dan Kepala Pemerintahan, tetapi Kepala Negaranya adalah Presiden yang dipilih dan bertanggung jawab kepada rakyat secara langsung seperti dalam sistem Presidensiil. Sedangkan Kepala Pemerintahan di satu segi bertanggung jawab kepada Presiden, tetapi di segi lain, ia diangkat karena kedudukannya sebagai pemenang pemilu yang menduduki kursi parlemen, dan karena itu ia bertanggung jawab kepada parlemen. ${ }^{30}$

Perbedaan ketiga sistem ini pada pokoknya terletak pada corak hubungan di antara kedua organ legislatif (parlemen) dan organ eksekutif (pemerintah) dalam susunan organisasi negara yang bersangkutan. Dalam sistem presidentil, pemerintah relatif merdeka dan tidak perlu bertanggung jawab kepada parlemen, akan tetapi pemerintah dalam sistem kabinet justru harus bertanggung jawab kepada parlemen. Prinsip pertanggungjawaban

26 Soewoto Mulyosudarmo, Pembaharuan Ketatanegaraan Melalui Perubahan Konstitisi, Cetakan Pertama, (Malang: Asosiasi Pengajar HTN dan HAN Jawa Timur dan In Trans, 2004). hlm. 102.

${ }^{27}$ Ibid.

28 Jimly Asshiddiqie, Hukum Tata Negara dan Pilar-Pilar Demokrasi, Cetakan Kedua, (Jakarta:Konstitusi Press, 2005), hlm. 109.

${ }^{29}$ Ibrahim R.. dkk (penyadur), Sistem Pemerintahan Parlementer dan Presidensial, Cetakan pertama, (Jakarta: PT. RajaGrafindo Persada, 1995), hlm. 14.

${ }^{30}$ Jimly Asshiddiqie, Hukum Tata Negara dan Pilar-Pilar Demokrasi, Cetakan Kedua, (Jakarta:Konstitusi Press, 2005), hlm. 109. 
pemerintah ini didasarkan atas doktrin pemisahan kekuasaan (separation of power) yang mula-mula dikemukakan oleh John Lock pada 1690 dan kemudian dikembangkan oleh Montesquieu pada pertengahan abad ke-18. ${ }^{31}$

Sistem pemerintahan parlementer menampakkan berbagai ciri utama. Pertama, ada dua kelembagaan eksekutif, yaitu eksekutif yang menjalankan dan bertanggung jawab atas penyelenggaraan pemerintahan dan eksekutif yang tidak adapat diminta pertanggungjawaban atas penyelenggaraa pemerintahan. Eksekutif pertama ada di tangan kabinet atau dewan menteri. Eksekutif kedua, adalah kepala negara, yaitu raja bagi kerajaan dan presiden bagi republik. Pertanggungjawaban eksekutif kedua, dilaksanakan oleh eksekutif pertama. Kedua, kabinet atau dewan menteri bertanggung jawab kepada badan perwakilan rakyat, sedangkan kepala negara tidak dapat diganggu gugat (can do no wrong). Maksud bertanggung jawab adalah eksekutif tersebut dapat dijatuhkan dengan mosi tidak percaya oleh badan perwakilan rakyat. ${ }^{32}$ Dalam sistem dua partai, yang ditunjuk sebagai pembentuk kabinet dan sekaligus sebagai Perdana Menteri adalah ketua partai politik yang memenangkan pemilu. Sedangkan dalam sistem banyak parti, formatur kabinet harus membentuk kabinet secara koalisi, karena kabinet harus mendapat dukungan kepercayaan dari parlemen. ${ }^{33}$ Sistem pemerintahan - parlementer atau presidensil - dapat berlaku dalam sistem politik atau ideologi apapun. Secara formal - sebelum bubar - Uni Soviet (Komunis) menjalankan sistem palementer, karena pemerinah bertanggung jawab kepada parlemen (Soviet Tertinggi), walaupun secara riil semua berada di bawah kendali Partai Komunis. Dalam praktik bukan Soviet Tertinggi yang menjarihkan Perdana Menteri, tetapi garis partai. ${ }^{34}$

Sementara itu, sistem presidensil hanya mengenal satu macam eksekutif. Fungsi kepala pemerintahan (chief executive) dan kepala negara (head executive). Pemegang kekuasaan eksekutif tunggal dalam sistem presidensil tidak bertanggung jawab kepada badan perwakilan rakyat, tetapi langsung kepada rakyat pemilih karena dipilih langsung atau dipilih melalui badan pemilih (electoral college). Sistem presidensil dapat dikatakan sebagai sub sistem pemerintahan republik, karena hanya dijalankan dalam negara yang berbentuk republik (sesuai dengan sebutannya sebagai sistem presidensil atau sistem pemerintahan kepresidenan). Sedangkan sistem parlementer dapat dijalankan baik pada negara republik ataupun kerajaan. ${ }^{35}$

31 Jimly Asshiddiqie, Pergumulan Peran Pemerintah dan Parlemen Dalam Sejarah Telaah Perbandingan Konstitusi Berbagai Negara, Jakarta, UI Press, 1996, hlm. 60.

32 Bagir Manan, Lembaga Kepresidenan, Cetakan Ketiga (Edisi revisi), (Yogyakarta: FH UII Press, 2006), hlm. 14.

33 Moh. Kusnardi, Harmaily Ibrahim, Hukum Tata Negara Indonesia, Cetakan Ketujuh, (Jakarta: Pusat Studi Hukum Tata Negara FH UI dan CV'Sinar bakti”, 1988), hlm. 175 .

${ }^{34}$ Bagir Manan, Teori dan Politik Konstitusi, Cetakan Pertama, (Yogyakarta: FH UII Press, 2003), hlm. 7-8.

${ }^{35}$ Bagir Manan, Lembaga Kepresidenan, Cetakan Ketiga (Edisi revisi), (Yogyakarta: FH UII Press, 2006), hlm. 14. 
Selain ketiga model itu, yang agak khas adalah Swiss yang juga mempunyai Presiden dan Wakil Presiden yang dipilih dari dan oleh tujuh orang anggota Dewan Federal untuk masa jabatan secara bergantian setiap tahun. Sebenarnya ke-tujuh orang anggota Dewan Federal itulah yang bersama-sama memimpin negara dan pemerintahan Swiss. Karena itu, sistem pemerintahan Swiss ini biasa disebut sebagai "collegial system" yang sangat berbeda dari tradisi presidentialisme atau parlementarisme. ${ }^{36}$

\section{Kedudukan MPR Sebagai Lembaga Tertinggi Negara}

Berdasarkan Pasal 1 ayat (2) UUD 1945 (Sebelum Perubahan) dan Penjelasan UUD 1945 bahwa, kekuasaan Negara yang tertinggi di tangan MPR. 35 MPR adalah lembaga Negara yang mempunyai kedudukan dan kekuasaan yang tertinggi. Kekuasaannya tidak terbatas dan tidak ditetapkan secara limitatif melainkan enunsiatif yang bersumber pada Pasal 1 ayat (2) itu sendiri. Dengan demikian Majelis mempunyai kedudukan yang tertinggi di antara Lembaga-lembaga Negara lainnya. Majelis inilah yang mengangkat Kepala Negara (Presiden) dan Wakil Kepala Negara yang tertinggi, sedang Presiden harus menjalankan haluan negara menurut garis-garis yang telah ditetapkan oleh Majelis. Presiden yang diangkat oleh Majelis, tunduk dan bertanggung jawab kepada Majelis. Ia adalah "Mandataris" dari Majelis, ia wajib menjalankan putusan-putusan Majelis. Presiden tidak "neben" akan tetapi “untergeordnet" kepada Majelis.

Dalam praktik ketatanegaraan Indonesia, ternyata baik pada MPRS masa Orde Lama maupun masa Orde Baru, semua anggotanya diangkat oleh Presiden. MPRS hanya berwenang menetapkan garis-garis besar daripada haluan negara. Ini berarti, bahwa Presiden telah mencampuri bahkan membatasi wewenang MPRS. Ismail Suny menyebutnya sebagai "wewenang yang terbatas", urusan-urusan intern Majelis banyak ditentukan oleh Presiden. Semua pimpinan MPRS dalam praktik adalah diangkat oleh Presiden sendiri. Dari praktik-praktik di atas maka semasa MPRS Orde Lama, Majelis bukan lagi sebagai lembaga negara yang tertinggi, MPRS mempunyai kedudukan di bawah Presiden. Para pimpinan MPRS yang diangkat adalah juga sebagai menteri yang memegang departemen-departemen, ini berarti kekuasaannya jelas berada di bawah Presiden berdasarkan Pasal 17 UUD 1945. Dengan demikian, pada MPRS masa 1960 s.d. 1965 bukanlah Lembaga Tertinggi Negara, tetapi suatu Majelis yang kedudukannya di bawah Presiden. ${ }^{37}$

Menyadari penyimpangan-penyimpangan UUD 1945 oleh lembagalembaga kenegaraan di atas, maka MPRS masa Orde Baru telah mulai menempatkan Majelis sebagai suatu lembaga negara yang tertinggi, dengan

36 Jimly Asshiddiqie, Hukum Tata Negara dan Pilar-Pilar Demokrasi, Cetakan Kedua, (Jakarta:Konstitusi Press, 2005), hlm. 110.

${ }^{37}$ Budiman B. Sagala, Tugas Dan Wewenang MPR, (Jakarta: Ghalia Indonesia, 1982), hlm.77. 
melaksanakan kewenangan-kewenangan sebagaimana tercantum dalam UUD 1945. Tetapi seluruh anggota MPRS adalah hasil pengangkatan/penunjukan Presiden sendiri. Di samping itu DPRGR Orde Baru pernah infunctie, tidak berfungsi karena beku, selama waktu hampir setahun. Hal ini jika diperhatikan pada saat anggota DPRGR telah berhenti sejak tanggal 28 Oktober 1971, saat dilantiknya anggota DPR RI hasil Pemilihan Umum. Dengan demikian otomatis berhentilah 414 orang dari 828 anggota MPRS. Menurut UUD 1945, anggota DPR merangkap anggota MPR. Dengan hilangnya separuh anggota MPRS, berarti praktis anggota MPRS pun tidak mungkin bisa melaksanakan tugas dan wewenangnya. Dilihat dari sudut materi ketatanegaraan maka MPRS sebagai Lembaga Tertinggi Negara telah bubar, akibatnya vakum hingga tanggal 1 Oktober 1972, saat dilantiknya anggota MPR RI hasil Pemilihan Umum. Memang secara formal, MPRS belum bubar berdasarkan Tap MPRS No. XLII/MPRS/1968, tetapi dalam arti materi Majelis itu tidak berfungsi lagi. Walaupun MPRS itu bersifat sementara, akan tetapi pada hakikatnya ia adalah sama dengan MPR yang dimaksudkan UUD 1945 serta menjalankan tugas dan wewenangnya sesuai dengan UUD $1945 .^{38}$

Bagaimanakah kedudukan MPR RI hasil Pemilihan Umum? Dari dua kali Pemilihan Umum yang telah diselenggarakan di bawah UUD 1945, boleh dikatakan bahwa MPR RI (periode 1972-1977 dan periode 1977-1982) diproses dan dibentuk oleh Pemilihan Umum. Memang secara yuridis, MPR RI adalah melalui proses pemilihan umum, namun tidak perlu disangkal bahwa anggota Majelis mayoritas merupakan pengangkatan dan penunjukan Presiden. Sejak berdirinya Republik Indonesia, telah ada pengakuan bahwa MPR adalah satu-satunya Lembaga Tertinggi Negara, bahkan oleh Majelis sendiri menyebutkan dirinya sebagai penjelmaan seluruh rakyat. Akan tetapi kenyataannya, dalam praktik ketatanegaraan, MPR adalah lembaga yang lemah dibanding eksekutif yang berada pada posisi yang lebih kuat. Belum pernah anggota Majelis sebagai Lembaga Tertinggi Negara meminta dan menilai pertanggungjawaban dari Presiden yang diangkat, padahal MPR berwenang untuk itu. ${ }^{39}$

Dalam Penjelasan Pasal 3 UUD 1945 (Sebelum Perubahan) menegaskan bahwa:"Oleh karena MPR memegang kedaulatan negara maka kekuasaannya tidak terbatas". Sejalan dengan itu, dalam Ketetapan MPR nomor I/MPR/1973 tentang Peraturan Tata Tertib Majelis Permusyawaratan Rakyat, menyatakan; "Majelis adalah penjelmaan seluruh Rakyat Indonesia dan merupakan Lembaga Tertinggi Negara pemegang dan pelaksana sepenuhnya kedaulatan Rakyat." Kemudian Predikat MPR sebagai Lembaga Tertinggi Negara semakin dikukuhkan Tap MPR No III/MPR/1978 tentang Hubungan Tata Kerja Lembaga Tertinggi Negara dengan/atau antar Lembagalembaga Tinggi Negara telah menentukan dan menempatkan kedudukan MPR sebagai Lembaga Tertinggi Negara. Dalam hubungan ini Sri Soemantri mengatakan bahwa: pemakaian istilah sebagai "Lembaga Tertinggi Negara"

\footnotetext{
${ }^{38}$ Ibid., hlm. 78.

${ }^{39}$ Ibid.
} 
dan "Lembaga Tinggi Negara" kurang tepat. Sebab perkataan "lembaganegara" adalah satu istilah yang mempunyai satu maksud dan pengertian. Istilah itu adalah padanan kata political institution. Dengan demikian seharusnya digunakan istilah "Lembaga Negara Tertinggi" dan Lembaga Negara Tinggi". ${ }^{40}$

Setelah adanya perubahan UUD 1945 dengan ditetapkan Pasal 5 ayat (1) dan Pasal 20 ayat (1) melalui Perubahan Kedua UUD 1945 resmi menganut pemisahan kekuasaan (separation of power) dengan mengembangkan mekanisme hubungan 'checks and balances' yang lebih fungsional. ${ }^{41}$ Dengan perubahan ini, ditambah lagi dengan diadopsinya ketentuan mengenai pemilihan Presiden secara langsung oleh rakyat sehingga Presiden tidak lagi bertanggung jawab kepada MPR, maka kedudukan MPR sebagai lembaga tertinggi negara mengalami perubahan mendasar. MPR kehilangan sebagian fungsi dan wewenangnya, kedudukan MPR tidak lagi sebagai lembaga tertinggi, namun merupakan lembaga negara yang sederajat dengan lembagalembaga negara lainnya seperti :Presiden, BPK, MA, MK, dan KY, sebagaimana terdapat dalam UU No. 22 Tahun 2003 tentang Susunan dan Kedudukan MPR, DPR, DPD, dan DPRD. Pasal 10 UU tersebut menyatakan bahwa, MPR merupakan lembaga permusyawaratan rakyat yang berkedudukan sebagai lembaga negara. Demikian pula dalam Ketetapan MPR RI Nomor II/MPR/2003 tentang Perubahan Kelima Atas Ketetapan MPR RI Nomor II/MPR/1999 tentang Peraturan Tata Tertib MPR RI Pasal 2 Ketetapan MPR RI Nomor II.MPR/1999 yang semula berbunyi: "Majelis adalah penjelmaan seluruh rakyat Indonesia dan merupakan lembaga tertinggi negara, pemegang dan pelaksana sepenuhnya kedaulatan rakyat." Diubah menjadi selengkapnya berbunyi: "Majelis adalah lembaga negara, pemegang, dan pelaksana kedaulatan rakyat menurut ketentuan Undang-Undang Dasar Republik Indonesia Tahun 1945.

Bagir Manan mengemukakan, ${ }^{42}$ perubahan kedudukan keanggotaan dan mekanisme keanggotaan MPR selain untuk menutup peluang penyalahgunaan sebagai jalan penyimpangan praktik dari kehendak UUD, di antaranya juga dimaksudkan sebagai jalan mewujudkan gagasan meniadakan kedudukan MPR sebagai lembaga tertinggi negara, MPR bukan satu-satunya lembaga yang melaksanakan kedaulatan rakyat. Setiap lembaga yang mengemban tugas-tugas politik negara dan pemerintahan (tidak termasuk kekuasaan kehakiman) adalah pelaksana kedaulatan rakyat dan harus tunduk dan bertanggung jawab kepada rakyat. Secara praktis, pembaruan dimaksudkan untuk meniadakan penyalahgunaan kedudukan MPR sebagaai lembaga tertinggi negara. Sebenarnya kedudukan tertinggi tersebut dapat dipertahankan, sepanjang diartikan: Pertama, sistem keanggotaan yang diperluas (anggota DPR

\footnotetext{
${ }^{40}$ Sri Soemantri, Ketetapan MPR(S) Sebagai Salah Satu Sumber Hukum Tata Negara, Cetakan Pertama, (Bandung: Remadja Karya, 1985),hlm. 42.

${ }^{41}$ Jimly Asshiddiqie. "Reformasi Hukum dan Konstitusi Mewujudkan Cita Negara

Hukum," Pidato Ilmiah Milad Ke-44 Universitas Ahmad Dahlan, Yogyakarta, hlm. 6.

${ }^{42}$ Bagir Manan, DPR, DPR dan MPR dalam UUD 1945 Baru, (Yogyakarta: FH-UII Press, Cet.1, 2003), hlm. 74-76.
} 
ditambah utusan daerah dan utusan golongan). Kedua, wewenang hanya terbatas pada hal-hal yang disebutkan dalam UUD (menetapkan UUD, menetapkan GBHN, memilih Presiden dan Wakil Presiden, mengubah UUD). Nampaknya Orde Lama lebih konsekuen, Ketetapan-Ketetapan MPRS (Orde Lama) hanya terbatas pada hal-hal yang disebutkan dalam UUD. Berbeda dengan Orde Baru, atas dasar kekuasaan tak terbatas, MPR menetapkan berbagai ketetapan di luar yang ditentukan dalam UUD seperti Ketetapan tentang Pemilihan Umum. Hal yang sama dilakukan oleh MPR masa Reformasi. Ketetapan-ketetapan MPR di luar wewenang yang ditentukan dalam UUD merupakan suatu tindakan melampaui wewenang, karena itu semestinya batal demi hukum. ${ }^{43}$

Gambaran di atas memaparkan metamorfosis MPR yang berkedudukan sebagai Lembaga Tertinggi Negara pada masa Orde Lama dan Orde Baru sampai menjadi Lembaga Tinggi Negara pada Orde Reformasi. Jika kita telisik, sepanjang sejarah perkembangannya (Orde Lama dan Orde Baru), peran MPR mengalami pasang surut. Adakalanya MPR berperan sangat kuat melebihi eksekutif kadang kala peran MPR terkooptasi oleh kekuasaan ekekutif yang dipimpin Presiden.

Demikian juga pada masa Reformasi, salah satu agenda reformasi yang dituntut oleh rakyat adalah pemberdayaan MPR. ${ }^{44}$ Sekalipun kedudukannya bukan lagi sebagai Lembaga Tertinggi Negara, pemberdayaan institusi kenegaraan ini dipandang penting karena Sidang Umum MPR 1999 mengambil putusan bahwa setiap tahun diselenggarakan Sidang Tahunan MPR. Penyelenggaraan Sidang Tahunan dimaksudkan untuk mendengarkan pidato Presiden mengenai pelaksanaan Ketetapan Majelis, sebagaimana tercantum dalam Ketetapan MPR No. I/MPR/1999 Pasal 1 butir 9 jo. Ketetapan MPR No. II/MPR/1999 Pasal 49 ayat (2). Di samping itu, untuk mengontrol semua lembaga tinggi negara yang ada terhadap tugas dan kewajiban yang telah diberikan kepadanya, khususnya kepada Presiden yang telah mendapatkan limpahan tugas dan wewenang, mandat MPR dalam rangka penyuksesan dan pengamanan pembangunan nasional. ${ }^{45}$

Pada masa pemerintahan Presiden Susilo Bambang Yudhoyono 20042014, tradisi Sidang Tahunan ditiadakan dan MPR hanya bersidang sedikitnya sekali dalam lima tahun. Peran MPR pun dalam penyelenggaraan fungsi kelembagaan negara lebih tercermin pada pelaksanaan tugas Pimpinan MPR sebagaimana diatur dalam UU Nomor 27 tahun 2009, khususnya dalam Pasal 15 ayat (1) huruf e "mengoordinasikan anggota MPR untuk memasyarakatkan Undang-Undang Dasar Negara Republik Indonesia Tahun 1945”. Selanjutnya, berdasarkan ketentuan Pasal 15 ayat (1) huruf g undang-undang ini dan Pasal 22 ayat (1) huruf g Peraturan Tata Tertib MPR, Pimpinan MPR menetapkan arah, kebijakan umum, program, dan anggaran MPR. Kebijakan umum dan

\footnotetext{
${ }^{43}$ Ibid.

44 H. M. Thalhah, Dinamika Ketatanegaraan Indonesia, (Yogyakarta: UII Press, 2001), hlm. 68.

${ }^{45}$ Bagir Manan, Kedaulatan Rakyat Hak Asasi Manusia dan Negara Hukum, (Jakarta: Gama Media Pratama, Cet. I, 1996), hlm 104. Lihat H.M. Thalhah, Ibid., hlm. 70.
} 
program MPR diterjemahkan dalam bentuk komitmen Pimpinan MPR untuk melaksanakan sosialisasi 4 (empat) pilar, yaitu Pancasila, Undang-Undang Dasar Negara Republik Indonesia Tahun 1945, bentuk Negara Kesatuan Republik Indonesia, dan nilai-nilai Bhinneka Tunggal Ika.

Pada kepemimpinan Presiden Joko Widodo-Yusuf Kalla saat ini, peran MPR mengalami peningkatan dengan dihidupkannya kembali tradisi Sidang Tahunan MPR, meski hanya sebatas mendengarkan. Mestinya, MPR perlu membahas laporan tahunan yang disampaikan Lembaga-lembaga Tinggi Negara, yang kemudian dapat dijadikan dasar untuk melakukan perbaikan dan peningkatan kinerja Lembaga-lembaga Tinggi Negara pada satu tahun ke depan. Terhadap laporan Lembaga-lembaga Tinggi Negara tersebut MPR menyampaikan rekomendasi, sebagaimana tercantum dalam konsideran "menimbang" huruf c, Ketetapan MPR No. VIII/MPR/2000.

Dengan cara seperti itu kinerja Presiden dan lembaga-lembaga negara lainnya dapat dikontrol dan di bahas secara kelembagaan, Presiden memberikan tanggapan dan penjelasan atas semua program yang telah dijalankan.

\section{GBHN dan Penguatan Peran MPR}

Secara umum, GBHN adalah merupakan haluan negara dalam garisgaris besar sebagai pernyataan kehendak rakyat, yang mempunyai landasan idiil Pancasila serta UUD 1945 sebagai landasan konstitusional. Pengertian GBHN dapat dilihat dalam arti formal dan materil. Dalam arti formal, GBHN adalah merupakan salah satu tugas MPR menurut Pasal 3 UUD 1945 (Sebelum Perubahan). Secara yuridis formal, GBHN merupakan pokok-pokok daripada langkah-langkah yang harus dilaksanakan pemerintah. Dalam arti materil, GBHN merupakan wewenang MPR menurut Pasal 1 ayat 2 UUD1945 (Sebelum Perubahan). GBHN harus benar-benar merupakan kehendak rakyat secara keseluruhan. Sebab itu, MPR mesti memperhatikan dinamika dalam masyarakat untuk menentukan haluan-haluan apa yang akan digunakan pada program dalam rangka untuk meningkatkan kesejahteraan dan kecerdasan rakyat, dalam arah mencapai terwujudnya masyarakat adil dan makmur. Oleh karenanya, GBHN merupakan amanat rakyat yang telah disanggupi untuk melaksanakan secara jujur, murni dan konsekuen. GBHN dapat berfungsi sebagai jaminan bahwa pertanggungjawaban Presiden kepada MPR dapat dinilai berdasarkan pelaksanaan GBHN itu sendiri. ${ }^{46}$

Setelah sekian tahun GBHN digunakan sebagai arah pembangunan nasional (terakhir Ketetapan MPR No. IV/MPR/1998 tentang GBHN), sejak adanya pemilihan Presiden dan Wakil Presiden secara langung GBHN tidak lagi digunakan, sebagai gantinya adalah RPJP yang berasal dari visi dan misi Presiden dan Wakil Presiden terpilih. Jika ada yang mengatakan bahwa GBHN dan RPJP adalah sama, memang benar. GBHN dan RPJP adalam sama-sama

\footnotetext{
${ }^{46}$ Budiman B. Sagala Tugas Dan Wewenang MPR, (Jakarta: Ghalia Indonesia, 1982), hlm. 96-97.
} 
sebagai arah pembangunan nasional tetapi sumbernya berbeda. GHBN berasal dari MPR sedangkan RPJP berasal dari visi dan misi Presiden dan Wakil Presiden terpilih. ${ }^{47}$

Pertanyaannya sekarang adalah, bagaimana jika Presiden dan Wakil Presiden berhalangan tetap dalam masa jabatannya secara bersamaan kemudian MPR memilih Presiden dan Wakil Presiden Sebagaimana diatur dalam Pasal 8 ayat (3) Perubahan UUD 1945. Apakah Presiden dan Wakil Presiden "pilihan MPR" akan melanjutkan RPJP Presiden dan Wakil Presiden yang notabene berasal dari partai politik yang berbeda dan mempunyai visi dan misi yang tidak sama, atau menggunakan RPJP yang baru. Berbeda jika menggunakan GHBN, Presiden dan Wakil Presiden "pilihan MPR" dapat meneruskan program yang bersumber dari GBHN tanpa adanya benturan visi dan misi.

Di samping itu, sebelum mengambil keputusan untuk kembali menggunakan GBHN sebagai arah pembangunan nasional, perlu mempertimbangkan hal-hal sebagai berikut: Pertama, harus diatur secara jelas siapa yang berwenang membuat GBHN. Di Indonesia, kenyataannya dan bahkan seakan-akan menjadi suatu konvensi bahwa yang mengajukan Rancangan GBHN selalu oleh Pemerintah kemudian diajukan kepada MPR. Sedangkan "pekerjaan" MPR hanyalah menyetujui lalu menetapkannya dan kemudian diberikan cap MPR. Apakah hal seperti ini akan terjadi pada MPR di kemudian hari. Hal ini menjadi polemik antara penulis-penulis Indonesia pada awal sampai pertengahan 1977.

Pembicaraan soal pihak mana yan berwenang membuat rancangan GBHN, tidak habis-habisnya dipertanyakan di masa itu. ${ }^{48} \mathrm{Kedua}$, dalam bentuk hukum apa GBHN dituangkan? Ketetapan MPR kah? Jika dalam bentuk ketetapan MPR, maka ketetapan MPR harus dihidupkan kembali. ${ }^{49}$ Untuk itu, perlu adanya penegasan tentang materi dan status hukum ketetapan MPR dalam sistem hukum Indonesia termasuk ketetapan MPR/S yang masih dinyatakan berlaku. Ketiga, apabila menggunakan GBHN, pranata pertanggungjawaban Presiden kepada MPR harus ditradisikan kembali sebagai bentuk laporan bahwa Presiden telah melaksanakan amanah rakyat yang

${ }^{47}$ Perbedaan antara haluan negara dan RPJP adalah sangat mendasar, bahwa jika haluan negara bersifat ideologis sementara RPJP bersifat teknokratik. GBHN, adalah sebagai arahan bagi pembangunan nasional, sedang RPJP lebih berisi penjabaran arah pembangunan nasional, yang berisi prioritas kerja program pembangunan yang bersifat teknokratis dan pragmatis. Haluan negara bersifat dinamis dan holistik, karena dibahas setiap lima tahun oleh seluruh anggota MPR yang merupakan representasi seluruh rakyat Indonesia. Hal ini berbeda dengan RPJP yang cenderung statis karena berbentuk undang-undang sehingga berpotensi membelenggu perencanaan pembangunan pada pemerintahan periode berikutnya. <http://www.republika.co.id/berita/mpr-ri/berita-mpr/16/06/21/o93ylg368>-iniurgensi-gbhn-menurut-para-pakar. Di akses tanggal 15 September 2016.

${ }^{48}$ Budiman S. Sagala, Tugas Dan Wewenang MPR, (Jakarta: Ghalia Indonesia, 1982), hlm, 98-99.

49 GBHN mempunyai norma abstrak, umum dan dauerhaftig, sehingga ketetapan MPR tentang GBHN dikategorikan sebagai ketetapan yang bersifat regeling (mengatur), produk hukumnya pun harus dengan ketetapan MPR bukan dengan keputusan MPR. Tentang sifat norma ketetapan MPR baca R. Nazriyah, MPR RI Kajian Terhadap Produk Hukum dan Prospek di Masa Depan, (Yogyakarta: FH UII PRESS, 2007). 
dituangkan dalam GBHN. Tentu hal ini akan mempengaruhi sistem pemerintahan presidensial yang berlaku setelah adanya pemilihan Presiden secara langsung. ${ }^{50}$

Jika semua agenda di atas mendapat "restu nasional" maka tidak dapat dihindari perubahan kelima UUD 1945 merupakan suatu keniscayaan. Kendati demikian, mengacu pada pembuatannya yang sejak semula dalam sejarahnya UUD 1945 memang didesain oleh para pendiri negara kita (BPUPKI-PPKI) sebagai UUD yang bersifat sementara, karena dibuat dan ditetapkan dalam suasana ketergesa-gesaan sebagaimana ungkapan Presiden Soekarno yang mengatakan: ${ }^{51}$

“... tuan-tuan semuanya tentu mengerti, bahwa Undang-Undang Dasar yang kita buat sekarang ini, adalah Undang-Undang Dasar sementara. Kalau boleh saya memakai perkataan: ini adalah UndangUndang Dasar kilat. Nanti kalau kita telah bernegara di dalam suasana yang lebih tentram, kita tentu akan mengumpulkan kembali majelis permusyawaratan rakyat yang dapat membuat Undang-Undang dasar yang lebih lengkap dan lebih sempurna."

Demikian juga pengalaman yang terjadi pada perubahan UUD 1945 di masa Reformasi yang terpengaruh suasana euforia sehingga perubahannya dilakukan tanpa grand design yang jelas, hasilnya pun masih banyak mengandung kelemahan.

Berkaitan dengan ini, K.C. Wheare pernah mengingatkan, mengapa konstitusi perlu ditempatkan pada kedudukan yang tinggi (supreme), supaya ada semacam jaminan bahwa konstitusi itu akan diperhatikan dan ditaati dan menjamin agar konstitusi tidak akan dirusak dan diubah begitu saja secara sembarangan. Perubahannya harus dilakukan secara hikmat, penuh kesungguhan dan pertimbangan yang mendalam. ${ }^{52}$

\section{Kesimpulan}

Berdasarkan uraian di atas dapat disimpulkan bahwa, sepanjang sejarah perkembangannya (Orde Lama dan Orde Baru), peran MPR mengalami pasang surut. Adakalanya MPR berperan sangat kuat melebihi eksekutif kadang kala peran MPR terkooptasi oleh kekuasaan ekekutif yang dipimpin Presiden. Demikian juga pada masa Reformasi, pemberdayaan institusi kenegaraan ini dipandang penting karena Sidang Umum MPR 1999 mengambil putusan bahwa setiap tahun diselenggarakan Sidang Tahunan MPR. Pada masa

50 Dalam sejarah sistem presidensialnya, di Indonesia memperlihatkan ragam persoalan sekaligus tantangan. Selengkapnya lihat Susanto Polamolo, "Presidensialisme di Indonesia Antara Amanah Konstitusi dan Kuasa Partai," dalam Jurnal Konstitusi, Vol. 13 No. 2 Juni 2016, hlm. 323 dst.

${ }^{51}$ Moh. Yamin, Naskah Persiapan Undang-Undang Dasar 1945, (Jakarta: Yayasan Prapanca, 1959), hlm. 410

${ }^{52}$ K.C. Wheare, Modern Constitution, (New York-Toronto-London Oxford: University Pres, Third Impression, 1975), hlm.7. 
pemerintahan Presiden Susilo Bambang Yudhoyono 2004-2014, tradisi Sidang Tahunan ditiadakan dan MPR hanya bersidang sedikitnya sekali dalam lima tahun, peran MPR hanya sebatas menjalankan tugas untuk menyosialisasikan hasil-hasil amandemen UUD 1945 dan melantik Presiden dan Wakil Presiden.

Pada kepemimpinan Presiden Joko Widodo-Yusuf Kalla saat ini, peran MPR mengalami peningkatan dengan dihidupkannya kembali tradisi Sidang Tahunan MPR, meski hanya sebatas mendengarkan. Mestinya, MPR perlu membahas laporan tahunan yang disampaikan Lembaga-lembaga Tinggi Negara, yang kemudian dapat dijadikan dasar untuk melakukan perbaikan dan peningkatan kinerja Lembaga-lembaga Tinggi Negara pada satu tahun ke depan. Terhadap laporan Lembaga-lembaga Tinggi Negara tersebut MPR menyampaikan rekomendasi. Dengan cara seperti itu kinerja Presiden dan lembaga-lembaga negara lainnya dapat dikontrol dan di bahas secara kelembagaan, Presiden memberikan tanggapan dan penjelasan atas semua program yang telah dijalankan.

Wacana untuk menggunakan kembali GBHN seiring upaya menguatkan peran MPR, perlu mempertimbangkan hal-hal sebagai berikut: pertama, harus diatur secara jelas siapa yang berwenang membuatnya. Kedua, dalam bentuk hukum apa GBHN dituangkan? Ketiga, jika menggunakan GBHN akan ada pertanggungjawaban Presiden kepada MPR, maka akan berpengaruh terhadap sistem pemerintahan yang selama ini dianut. Ada baiknya jika menggunakan GBHN sebab, jika Presiden dan Wakil Presiden berhalangan tetap secara bersamaan dan MPR memilih Presiden dan Wakil Presiden sesuai amanat konstitusi, maka Presiden dan Wakil Presiden "pilihan MPR" dapat melanjutkan program pembangunan yang bersumber dari GHBN tanpa adanya benturan visi dan misi. Untuk itu, pengaturannya harus dikembalikaan kepada UUD, amandemen ulang merupakan suatu keniscayaan. 


\section{Daftar Pustaka}

\section{Buku}

Asshiddiqie, Jimly. Hukum Tata Negara dan Pilar-Pilar Demokrasi, Cetakan Kedua, Jakarta: Konstitusi Press, 2005. . Format Kelembagaan dan Pergeseran Kekuasaan Dalam

UUD 1945, Cetakan Pertama, Yogyakarta: FH UII Press, 2004. Konstitusi dan Konstitusionalisme Indonesia, Cetakan Pertama, Jakarta: Diterbitkan atas kerja sama: Mahkamah Konstitusi dan Pusat Studi Hukum Tata Negara FH UI, 2004.

Sejarah Telaah Perbandingan Konstitusi Berbagai Negara, Jakarta: UI Press, 1996.

Ibrahim R. dkk (penyadur), Sistem Pemerintahan Parlementer dan Presidensial, Cetakan pertama, Jakarta: PT. RajaGrafindo Persada, 1995.

Kusnardi, Moh., Harmaily Ibrahim. Hukum Tata Negara Indonesia, Cetakan

Ketujuh, Jakarta: Pusat Studi Hukum Tata Negara FH UI dan CV. Sinar bakti 1988.

Mahfud MD, Moh. Perdebatan Hukum Tata Negara Pasca Amandemen Konstitusi, Cetakan ke 2, Jakarta: PT. RajaGrafindo Persada, 2011.

Manan, Bagir. Lembaga Kepresidenan, Cetakan Ketiga (Edisi revisi), Yogyakarta: FH UII Press, 2006.

UII Press, 2003. -. Teori dan Politik Konstitusi, Cetakan Pertama, Yogyakarta: FH Yogyakarta: FH-UII Press, 2003. . Kedaulatan Rakyat Hak Asasi Manusia dan Negara Hukum, Jakarta: Gama Media Pratama, Cet. I. 1996.

Mulyosudarmo, Soewoto. Pembaharuan Ketatanegaraan Melalui Perubahan Konstitisi, Cetakan Pertama, Malang: Asosiasi Pengajar HTN dan HAN Jawa Timur dan In Trans, 2004.

Nazriyah, R. MPR RI Kajian Terhadap Produk Hukum dan Prospek di Masa Depan, Yogyakarta: FH UII PRESS, 2007.

Sagala, Budiman B. Tugas Dan Wewenang MPR, Jakarta: Ghalia Indonesia, 1982.

Soemantri, Sri. Kedudukan Lembaga-lembaga Negara dan Hak Menguji Menurut UUD 1945, Cetakan Pertama, Jakarta: Sinar Grafika, 1987. Ketetapan MPR(S) Sebagai Salah Satu Sumber Hukum Tata Negara, Cetakan Pertama, Bandung: Remadja Karya, 1985.

Soeprapto, Maria Farida Indrati. Ilmu Perundang-undangan Dasar-Dasar dan Pembentukannya, Yogyakarta: Kanisius, 1998.

Subekti,Valina Singka. Menyusun Konstitusi Transisi: Pergulatan Kepentingan dan Pemikiran dalam Proses Perubahan UUD 1945, Jakarta: Rajawali Pers, 2008.

Suny, Ismail. Mekanisme Demokrasi Pancasila. Jakarta. Aksara Baru. 1978. 
Thalhah, H. M., Dinamika Ketatanegaraan Indonesi, Yogyakarta: UII Press, 2001.

Wheare, K.C. Modern Constitution. Third Impression, New York-TorontoLondon Oxford: University Pres, 1975.

Yamin. Moh. Naskah Persiapan Undang-Undang Dasar 1945, Jakarta: Yayasan Prapanca, 1959.

\section{Peraturan Perundang-undangan}

UUD 1945 Sebelum Perubahan

UUD 1945 Setelah Perubahan.

Indonesia, Undang-Undang Tentang MPR, DPR, DPD, dan DPRD, UU Nomor 27 Tahun 2009, LN No. 123 Tahun 2009.

Indonesia, Undang-Undang Tentang Sususnan dan Kedudukan MPR, DPR, DPD, dan DPRD. UU No. 22 Tahun 2003 LN No. 92 Tahun 2003

Indonesia, Undang-Undang Tentang Sistem Perencanaan Pembangunan Nasional, UU No. 25 Tahun 2004 LN No. 104 Tahun 2004.

Ketetapan MPR No. VIII/MPR/2000 Tentang Laporan Tahunan Lembagalembaga Tinggi Negara pada Sidang Tahunan MPR RI Tahun 2000

Ketetapan MPR No. I/MPR/1999 Tentang Perubahan Kelima ata Ketetapan MPR No. I/MPR/1983 Tentang Peraturan Tata Tertib MPR RI.

Ketetapan MPR No. II/MPR/1999 Tentang Peraturan Tata Tertib MPR RI

Ketetapan MPR No. IV/MPR/1999 tentang Garis-Garis Besar Haluan Negara

Ketetapan MPR RI Nomor II/MPR/2003 tentang Perubahan Kelima Atas Ketetapan MPR RI Nomor II/MPR/1999 tentang Peraturan Tata Tertib MPR RI

Ketetapan MPR Nomor I/MPR/1973 tentang Peraturan Tata Tertib Majelis Permusyawaratan Rakyat.

Ketetapan MPR No III/MPR/1978 tentang Hubungan Tata Kerja Lembaga Tertinggi Negara

\section{Artikel}

Asshiddiqie, Jimly, "Struktur Ketatanegaraan Indonesia setelah Perubahan Keempat UUD Tahun 1945." Makalah disampaikan pada : Seminar Pembangunan hukum Nasional VIII Tema "Penegakan Hukum Dalam Era Pembangunan Berkelanjutan" Diselenggarakan oleh Badan Pembinaan Hukum nasional Departemen Kehakiman dan Hak Asasi Manusia RI. Denpasar, 14 - 18 Juli 2003.

. Reformasi Hukum dan Konstitusi Mewujudkan Cita Negara Hukum. Pidato Ilmiah Milad Ke-44 Universitas Ahmad Dahlan. Yogyakarta. 
Nirahua, Salmon E.M., "Kedudukan dan Kewenangan Dewan Perwakilan Daerah dalam Sistem Ketatanegaraan Indonesia," dalam Jurnal Hukum Ius Quia Iustum, Vol. 18 No. 4, Yogyakarta, Oktober 2011.

Polamolo, Susanto, "Presidensialisme di Indonesia Antara Amanah Konstitusi dan Kuasa Partai," dalam Jurnal Konstitusi, Vol. 13 No. 2 Juni 2016.

Wasti, Ryan Muthiara." Pengaruh Konfigurasi Politik Terhadap Produk Hukum Pada Masa Pemerintahan Soeharto Di Idonesia", Jurnal Hukum dan Pembangunan, Tahun ke-45 No.1 Januari-Maret 2015

\section{Websites}

http://perpustakaan.bappenas.go.id. MPR Pasca perubahan UUD 1945.htm. Diakses tanggal 25 Mei 2012.

http://kabar24.bisnis.com/read/20140922/15/259180/kedudukan-mpr-hindarimunculnya-lembaga-otoriter. Di akses tanggal 15 September 2016.

http://www.republika.co.id/berita/mpr-ri/berita-mpr/16/06/21/o93ylg368-iniurgensi-gbhn-menurut-para-pakar. Di akses tanggal 15 September 2016. 